\title{
A paradigm shift in pastoral ministry in twenty-first century Nigeria: An examination of the trends, causes and its implications
}

\author{
Biwul, Joel Kamsen Tihitshak \\ Stellenbosch University \\ jbiwul@yahoo.com
}

\begin{abstract}
The paradigm shift in pastoral ministry in contemporary Nigeria is detrimental to the church and the gospel. This article examines the emerging trends as well as the motivating factors and implications of this shift. It argues that the emerging distortions are rooted in a lack of basic knowledge of the biblical, theological and ethical foundations and established traditions of the ministry, and argues for an honest return to those foundations.
\end{abstract}

Keywords

Church, contemporary, flock, foundation, ministry, Nigeria, paradigm shift, pastoral

\section{Introduction}

The twenty-first century has been marked by a global shift away from the basic scriptural paradigm of pastoral ministry. Eugene Peterson laments this in an American context:

American pastors are abandoning their posts, left and right, and at an alarming rate. They are not leaving their churches and getting other jobs. Congregations still pay their salaries. Their names remain on the church stationary and they continue to appear in pulpits on Sundays. But they are abandoning their posts, their calling. They have gone whoring after other gods. What they do with their time under the guise of pastoral ministry hasn't the remotest 
connection with what the church's pastors have done for most of twenty centuries ... The pastors of America have metamorphosed into a company of shopkeepers, and the shops they keep are churches. They are preoccupied with shopkeeper's concerns how to keep the customers happy, how to lure customers away from competitors down the street, how to package the goods so that the customers will lay out more money. ${ }^{1}$

A similar paradigm shift in pastoral ministry is being witnessed in Nigeria. Nigerian pastors in both mainline and independent churches are increasingly abandoning the responsibility of keeping the flock attentive to God. As Peterson points out, this amounts to a grave dereliction of pastoral responsibility. The pastoral office and ministry have been "badly shaken and bruised" and are in dire need of salvaging and mending. ${ }^{2}$

This study employs a survey research as it asks: What indicators in the application of pastoral ministry in contemporary Nigeria suggest that there is a shift in paradigm? What are the likely motivating factors that have contributed to this shift? Lastly, what does this shift portend for the ministry and the church in Nigeria today? The answers to these questions were sought in a random survey of pastors from a wide spectrum of church denominations (mainline and independent churches) in Nigeria. The sampled population consisted of fifty-nine graduate students of ECWA Theological Seminary, Jos, Nigeria. A research questionnaire with the three open-ended questions above was administered and the responses were categorised according to emerging themes from each question and were reported in percentages.

1 Eugene H. Peterson, Working the Angles: The Shape of Pastoral Integrity (New ed., Grand Rapids, Michigan: William B. Eerdmans Publishing, 1993; reprinted, 1996), pp. 1,2 .

2 Thomas C. Oden, Pastoral Theology: Essentials of Ministry (New York: HarperCollins Publishers, 1983), p. 5. 


\section{Indicators of the paradigm shift in contemporary pastoral ministry}

\subsection{Shift in biblical foundation for pastoral ministry}

Many who are engaged in the pastoral ministry in Nigeria today are impoverished in the biblical grounding for the ministry. They lack adequate biblical knowledge of the nature and function of the pastoral office. As Thomas Oden warns, "It is dangerous to the health of the church for ministry to be practiced without good foundation in Scripture and tradition, reason and experience."3

A pastor's need for biblical knowledge flows from the fact that "the biblical documents themselves are in many cases written as pastoral documents." ${ }^{4}$ The Old Testament writings and the gospels and epistles are all couched in clear pastoral tones because the Scripture itself is an embodiment of God's love and his purposeful agenda for humanity's good. Consequently, every claim or engaged activity must have the Scripture as its starting point to be accredited as "pastoral ministry".

However, today there are some who claim to be pastors who understand the pastoral function from an African socio-cultural and traditional religious point of view without recourse to the biblical tradition. Their orientation and practice of ministry is guided by that worldview and those beliefs. The Bible is used only as a tool to Christianize their activities and is often perceived as possessing magical power to confront the many ills of African society. ${ }^{5}$

A number of these so-called pastors (as 22\% from the research revealed) are in ministry not because they are called to the ministry but because they want to escape joblessness. As one respondent put it, "Some ministers, pastors, evangelists and missionaries are not called by God. They only force themselves into the pastoral ministry." When pastoral ministry

3 Oden, Pastoral Theology, p. xii.

4 D. J. Tidball, "Practical and Pastoral Theology," in David J Atkinson, David H. Field, Arthur F Holmes, and Oliver O'Donovan (eds.), New Dictionary of Christian Ethics and Pastoral Theology; Leicester, England: IVP, 1995), p. 43.

5 Matthew Michael, Christian Theology and African Traditions (Eugene, Oregon: Resource Publications, 2013), p. 63. 
is approached from a socio-economic perspective without significant emphasis on the biblical roots, a shift in paradigm becomes obvious.

Fundamentally, Scripture reveals the pastoral office as a called one. As Robert C. Anderson asserts, a pastor "is an ordinary person who knows the Lord Jesus Christ as his personal Saviour, has experienced the call of God in his life for full-time Christian service, and knows that he is fit for such service because he meets certain biblical character qualifications." ${ }^{6}$. $\mathrm{He}$ also rightly asserts, "Not everybody can be a pastor - only those who meet the biblical requirements, sense the call of God on their lives, and have the appropriate gifts needed to make the office a success." 7 The presence of people in the pastorate who fail to live up to these requirements suggests a distortion of the pastoral ministry.

A significant number of respondents (32.3\%) confirmed that some who are in the pastorate today are not called to the office. One respondent said, "Most people come into the pastoral ministry for food, job, and as a last option; not because they are called into the ministry. So, they serve as hired hands, not as good shepherds". Paul described such people as "peddlers of God's word" (2 Cor 2:17; 11:13-15). Some are even wolves in sheep's clothing, deliberately setting out to distort the truth and devour their prey (Matt 7:15; 10:16).

To sum up, the presence of misinformed, unguided, and untrained people in the pastoral ministry distorts the biblical text and corrupts the ministry. Just as there were false prophets in the Old Testament and false apostles in the New Testament, so there are false pastors, preachers, evangelists, and missionaries in the ministry today.

\subsection{Shift in theological foundation for pastoral ministry}

Pastoral ministry has a theological foundation. This foundation is reflected in the metaphors that are used for pastoral ministry, the most prominent of which is that a pastor is a shepherd. In biblical times, the term shepherd was used both literally and metaphorically. Literally, a shepherd was a herder

6 Robert C. Anderson, The Effective Pastor: A Practical Guide to the Ministry (Chicago, Illinois: Moody, 1985), p. 4.

7 Ibid., p. 22. 
who cared for sheep; metaphorically, the term referred to those who were in political or religious leadership. Using the same metaphor, the kings of Israel, and even Yahweh himself, are referred to as shepherds of Israel in the Old Testament, and Jesus referred to himself as the good shepherd in the New Testament (Jn 10). Self-sacrifice, care, love, mercy and compassion, provision and protection are demonstrated to be the qualities of a true shepherd. The apostles adopted this metaphoric understanding in their letters in which they expounded the Christological theology of pastoral ministry. ${ }^{8}$ As a shepherd, the pastor carries the weighty responsibility of protecting and preserving the flock (1 Pet 5:1-4).

Next, the pastor is described as a servant (Rom 1:1; Gal 1:10; 2 Cor 6:4; $11: 23)$ because the responsibilities of the pastoral ministry are primarily geared towards offering service to the believing community by attending to their spiritual, socio-economic, and material needs. This idea too is found repeatedly in Yahwistic, prophetic, apostolic, and Christological ministry models.

Thirdly, the pastor is described as a steward (1 Cor 4:1; Titus 1:7) who serves as a custodian of the Word of God and the flock of Christ. The stewardship metaphor stresses that a pastor's "responsibility is to manage the resources and fulfil the commission of [the] master rather than to create any basis for ministry in himself or herself" ${ }^{9}$ Paul testifies to what this means when he describes his own ministry in Acts 20:17-31.

Furthermore, the pastor is an overseer (1 Cor 9:27; Heb 13:17; 1 Pet 5:1-4). This function emphasizes the crucial responsibility of exercising spiritual oversight, a role that has preventive, protective and corrective overtones. As an overseer, the pastor instructs the church in Scripture, doctrine, theology, and Christian ethics, with the basic aim of correcting wrong doctrine and bad theology. The goal is to prevent the flock from feeding on spiritual chaff that will produce a malnourished, distorted, and misguided Christian spirituality.

8 The theology of pastoral ministry is distinct from pastoral theology and from the theology of ministry. Here, the term refers to the adequate foundational understanding of the nature, purpose and methodology of pastoral ministry. It also concerns itself with the identity of the pastor and the pastoral calling.

9 Tidball, "Practical and Pastoral Theology," p. 46. 
All the metaphors for pastoral ministry presuppose that the effectiveness and success of the pastoral ministry are anchored primarily in the pastor's intimate relationship with God and Jesus. He is the Master all true pastors serve. Pastoral ministry is also anchored in a cordial relationship with the flock. The type of relationship required is modelled in the life of Jesus (Jn $10: 1-5,9-14,27-29)$ and in the ministry of Paul (Gal 2:8-9; 4:14-15; Phil $1: 4-5,8 ; 1$ Thess $2: 6-8$ ). Tidball observes, "The quality of relationship, implicit in the shepherding motif, is vital in determining the success of pastoring. ... [For the true shepherd] always sensitively takes account of [the flock's] needs, situations and personalities." ${ }^{10}$ Thus the theological foundation of the pastoral ministry presupposes a deep, Christ-like passion for the lost and great care for the saved. It is a ministry that demands sacrifice because of numerous risks and the unquantifiable demands that the Lord places on it.

Unfortunately, many claimants to the pastoral ministry in Nigeria are more self-centred than sheep-centred. They fail to pay careful attention to the functional descriptions of the pastoral identity discussed above and to the demands of the ministry. As a result, the theological foundation for their vital ministry is slipping from their grasp. A number of the respondents to the survey (17\%) agreed that there are pastors who care more about their personal benefits than they do for the needs of church members. When pastoral ministry is approached from a humanistic perspective rather than from the standpoint of biblical theology, a negative shift in paradigm is unavoidable.

\subsection{Shift in ethical foundation for the pastoral ministry}

When a pastor neglects the guiding ethics and etiquettes of the pastoral ministry, it amounts to a shift in its established paradigmatic ethical norms and values. Richard Gula points out,

We judge the effectiveness of ministers in terms of the congruence of their beliefs, personal life, and performance with the Christian message. The moral character and virtues of ministers are revealed in the moral responsibilities they assume and in how they act. How

10 Tidball, "Practical and Pastoral Theology," p. 46. 
they exercise their professional role as pastoral ministers depends a great deal on who they are. ${ }^{11}$

Moral character and integrity ${ }^{12}$ are essential virtues for the pastorate. This much is apparent from the list of qualifications for ministry handed down to Timothy (1 Tim 3). People in pastoral ministry neglect this to their peril and to the detriment of the ministry. This is, in part, because "Christianity is a behavioural religion; a Faith that is seriously concerned with the quality of living both in the context of spiritual fellowship with God, as well as in our social or corporate relationships... The Gospel ministry demands that anyone who will play any role in it must possess the Christ-like quality of life." 13

What generates moral character and integrity in a pastor is the active presence and operation of the Holy Spirit in a life that is transformed and submits consistently to the Lordship of Christ. As R. C. Roberts states, "Christian character is not just shaped by a theory of human nature, or even stories about a paradigm individual, or promises of a kingdom to come; it is a responsiveness to a living word of the living and present God." ${ }^{14}$

The virtues of spirituality, moral character, cognitive maturity and integrity for the pastoral ministry are no longer the guiding principles for many in ministry in twenty-first century Nigeria. Even some established mainline denominations often gloss over these crucial virtues when engaging new pastors. They instead, as respondents indicated, place a premium

11 Richard M. Gula, Ethics in Pastoral Ministry (Mahwah, New Jersey: Paulist Press, 1996), p. 31.

12 R. C. Roberts explains the difference between character and integrity as follows: A person has character if he or she is characterized by such traits as truthfulness, courage, justice and compassion, especially if that person is able to maintain virtuous action, emotion and thought despite pressures to slacken his or her measure ... A person is said to have integrity if he or she is a complete and definite self and has powers to resist 'disintegration' in the face of temptation, suffering, peer pressure, and other adverse moral influences. To have moral integrity is to be, and to be able to remain, a moral entirety - that is, a person in the fullest and deepest sense. (See R. C. Roberts, "Character," in David J. Atkinson, David H. Field, Arthur F. Holmes, and Oliver O'Donovan (eds.) New Dictionary of Christian Ethics and Pastoral Theology (Leicester, England: IVP, 1995), p. 65.)

13 John C. Onwuka, The True Minister of God ( $3^{\text {rd }}$ rev. ed.; Bukuru, Nigeria: ACTS, 2011), p. 68.

14 Roberts, "Character," in New Dictionary of Christian Ethics and Pastoral Theology, p. 69. 
on having a godfather, one's ethno-tribal background, the section of the country one comes from, and political sentiments (18.6\%); and academic attainment (8.5\%). The effect of this shift can easily be seen in the lack of ethical behaviour on the part of some pastors, which manifests itself in the following ways:

\subsubsection{Self-centredness and materialism}

Until recently, pastors in most mainline church denominations were never given meaningful salaries or stipends. The thinking was that a pastor's reward would come in heaven, not in the here and now. So pastors and their families were left to fend for themselves. Fortunately, today most mainline denominations do give all pastors some kind of salary, allowance, or stipend.

While it was wrong for the denominations to ignore economic realities, those pastors did at least rely on God to meet their needs. Today, however, many Nigerian pastors seem to have forgotten all about the Christian principle of contentment (Mt 6:24-34; 1 Tim 6:5-10; 2 Tim 3:1-2) and have bought into a materialistic ideology, to the detriment of the flock and to the discredit of the ministry. As a result, their focus has often shifted from the basics of winning souls and working hard to build up the faith of church members to a desire to derive material benefits from the ministry.

A majority of the respondents (56\%) said that most contemporary Nigerian pastors assign a higher priority to materialism than to pastoral care and function. One respondent said that this shift is happening because there is "no fear of the Lord, no love for the Lord and for his people in the hearts of most pastors".

Onwuka sees “'ministers' glorying, boasting, and defining ministerial success in terms of the quality of clothes they wear, the type of cars they drive, the amount of salary they earn, and even in some cases the type of television they have in their parlour." ${ }^{15}$ Some of these pastors are particular about the type and model of the mobile phone and iPad/tablet they use.

15 Onwuka, The True Minister of God, p. 132. 
The rise of materialism among some pastors has led to their being described as "Men of Gold" rather than Men of God. ${ }^{16}$ They are the Gehazis of our day, who are not concerned about spiritual things but about material things. ${ }^{17}$ Zachariah Chinne describes them as "gospel merchants" who "possess predatory skills akin only to carnivorous animals that lie in wait for their prey with [the] intent to pounce on them at the slightest opportunity." ${ }^{18}$

Materialistic ministers resort to coercion, manipulation, threats and dictatorial behaviour to squeeze more financial and material wealth from their congregations. By becoming self-seeking and materialistic in their ministry, they put themselves in the position of being enemies of God (1 Sam 2:29-30; Micah 3:9-12; Mal 1:6).

\subsubsection{Emphasis on status}

Pastoral ministry in this generation is no longer based upon the Scripture as its guide nor on Jesus as its model. Instead, other human beings set the standard. This has resulted in a competitive spirit as pastors seek to be like or to surpass some other pastor. Such a spirit eats away at ministry like a feasting maggot. It leads, as a significant number of the respondents reported (32.2\%), to pastors either preaching a cheap gospel or watering down biblical preaching to pull and maintain a crowd. Others (20.6\%) said that pastors who focus on status normally deemphasize missions, evangelism and discipleship because the focus of their preaching is prosperity and miracles - and they may not always be honest and truthful in their preaching.

The research (47.4\%) revealed that a good number of Nigerian pastors are characterized more by pride than by humility and are driven by a thirst for status, authority, and popularity. They want to be seen to be in charge; to be seen to be displaying power and performing the extraordinary in ministry. The concept of anointing (erroneously understood) is taking centre stage in ministry instead of the preaching of the true gospel. Some pastors attempt to bolster their status by projecting information about their status and

16 Zachariah Chinne, Men of Gold: Rescuing the Church from the Throes of Material "Men of God" (Bukuru, Nigeria: Hamtul Press Ltd., 2013).

17 Samaila Hato Nahor, Peddling the Gospel for Personal Profit: A Theology for Church and Mission Practice (Jos, Nigeria: Inspiration Publishers, 2015), pp. 82-88.

18 Chinne, Men of Gold, p. 37. 
credentials on screens that are displayed before the church members to convince them that the one who stands before them is "anointed" with power to perform wonders.

Raphael O. Olori has studied this quest for power in the Nigerian version of the prosperity gospel, which he attributes to the ideology of dominion and domination; power and authority to possess and exercise one's authority over sickness, poverty, demons and bad luck; and the quest to remain in power for the benefit of personal veneration and dominance over one's church members. He reports that pastors will look outside the church for some source of additional power to enable them to sustain their ministry gymnastics. ${ }^{19}$

But power and authority in pastoral ministry do not and cannot originate from satanic sources. They come only from Christ and flow only through a humble heart that kneels daily at the foot of the cross. Even the great Apostle Paul acknowledged that Christ was the source of his power and success in ministry, saying, "I can do all things through him who strengthens" (Phil 4:13). True ministers should seek to "be strong in the Lord and in the strength of his might" (Eph 6:10).

The true model for pastors should be the one the Apostle John sketched for us when he described the simple lifestyle and humble attitude of John the Baptist, who said of himself, "I am not the Christ" (John 1:20) and was content to describe himself as "the voice of one crying out in the wilderness, "Make straight the way of the Lord"' (In 1:23). He testified that he was not worthy to untie the strap of Christ's sandal (Jn 1:27 NIV). This paradigm of humility is fast being replaced by the glorification of self.

\subsubsection{Pandering to the congregation}

Because of the prevalence of distorted pastoral ministry, many Christians can scarcely untangle good from bad biblical doctrine or differentiate between false and true Christian spirituality. Anything that is thrown at them is accepted as good. There is a general ignorance of what Scripture

19 Raphael Onovughe Olorin, "Simon the Sorcerer and the Employment of Magical Powers by Pastors and Evangelists for Miracles and Church Growth in Nigeria," in S. O. Abogunrin (ed.), Biblical Studies and Corruption in Africa. Biblical Studies Series Number 6. (Nigeria: The Nigerian Association for Biblical Studies, 2007), pp. 483-487. 
teaches, and little desire to seek such knowledge. To compound this problem, a growing number of worshippers are becoming spiritual dissidents, demanding that their pastors give them what appeals to them or they will leave the church. This is the same scenario that was envisaged by Paul: "For the time will come when [church members] will not put up with sound doctrine. Instead, to suit their own desires, they will gather around them a great number of teachers to say what their itching ears want to hear. They will turn their ears away from the truth and turn aside to myths" (2 Tim 4:3-4 NIV). Peterson describes this as a conspiracy to eliminate what is most important in the ministry.

Pastors who are not firmly rooted in the Scriptures can easily yield to such demands, forgetting the ministerial imperative, "But you [minister of God], keep your head in all situations, endure hardship, do the work of an evangelist, discharge all the duties of your ministry" (2 Tim 3:5 NIV). Personal conviction, boldness and firmness are necessary if one is to be able to remain faithful and steadfast in doing what is right when many are giving in to popular demands. But dereliction of duty and abandoning your primary obligation, responsibility and accountability to God in favour of the demands of an erring flock is very risky. King Saul was not exonerated from divine judgement because of the context that informed his wrong action (1 Sam 13:5-14; 15:19-27).

\subsubsection{Lack of respect for seniority}

African cultures have a long tradition of respect for one's elders, but this value is now being eroded. We are now seeing examples of blatant disrespect of the elderly and senior colleagues by junior pastors, who are expected to be models to the flock. This disrespect extends even to those under whom such pastors serve as subordinates. But ministerial respect for seniority is not only cultural but Scriptural. For example, there was first a Moses before there was a Joshua; there was an Elijah before there was an Elisha; and there was a Paul before there were Timothy and Titus. None of these accounts of the relationships between these leaders indicates any disregard or disrespect for superiors.

This paradigm shift results in younger pastors refusing to accept any correction or guidance from senior pastors, even when the correction offered is biblical. The arrogance of the younger pastors means that they 
want to do pastoring on their own terms rather than on God's terms. Their godless, immature and insensitive spiritual attitude often causes them to become arrogant and boastful.

The ethical failings outlined above leave the flock confused, misguided, disenfranchised and spiritually malnourished. Instead of being inspired by the lives of their pastors as examples of right conduct, ${ }^{20}$ they are discouraged by their negative attitudes and ungodly character. Some respond by adopting the same twisted and rebellious attitudes modelled by their pastors, others (as 20.3\% indicated) move on to find another church, where they may again fall prey to predatory prophets.

\subsection{Shift in professionalism}

Every profession requires that those who practise it manifest professional competence and maintain professional ethics, that is, "the moral character and the sum of obligations that pertain to the practice of a profession." ${ }^{21} \mathrm{~A}$ true professional "is committed to standards of integrity and performance that cannot be altered to suit people's tastes or what they are willing to pay for." 22

Just as a medical doctor is a specialist in the diagnosis and treatment of physical ailments, so the pastor as a spiritual specialist and expert must be "a spiritual physician, [who] knows how to diagnose [people's] cases and to rightly apply the medication of the Word of God to their spiritual needs." ${ }^{23}$ Church members look to the pastor for help, direction and guidance. "They count on him as one who has medicine for their sickness, knowledge for their ignorance, light for their darkness, wisdom for their foolishness, guidance for their confusion, counselling for their mistakes and misbehaviours, comfort for their sorrows, balm for their wounds, sight for their blindness, and direction for their journey." ${ }^{24}$

20 Samuel Waje Kunhiyop, African Christian Ethics (Nairobi, Kenya: Hippo Books, 2008), p. 62 .

21 Gula, Ethics in Pastoral Ministry, p. 3.

22 Peterson, Working the Angles, p. 5.

23 Onwuka, The True Minister of God, p. 29.

24 Ibid. 
With such high trust and confidence reposed in the pastor and the pastoral ministry, those who lay claim to the pastoral function cannot afford to fail God's people in any way. Gula notes, "The proper exercise of their ministry requires expert knowledge and skill and good moral character to serve the religious needs of the people." 25

However, many so-called pastors in contemporary Nigeria display glaring incompetence in the pastorate. Some lack administrative skills and the capacity to give leadership. Many know nothing of church history and the reasons for the established traditions for ministry in the denominations within which they serve as pastors. They are incompetent in the execution of the liturgical traditions and in the administration of the various sacraments. Worst, they are incompetent in the way they handle the biblical text in the pulpit.

When professional expertise is downplayed and egocentric, untrained, arrogant and careless people find their way into the pastorate, there is little hope that pastors will develop the needed professional expertise.

\section{The causes of the paradigm shift in contemporary pastoral ministry}

\subsection{Wrong perception of the ministry}

The envy of Aaron and Miriam led them to become sarcastic and disrespectful to their brother Moses (Num 12:1-5). Miriam, who had once led in singing and dancing, became grumbling and accusatory (Ex 15:20-21). Simon Magus was envious of the power of God in the ministry of Philip and Peter and offered money in exchange for their power (Acts 8:9-24). The sons of Sceva became envious of the ministry of Paul and tried to arrogate to themselves the power they saw at work in his ministry (Acts 19:13-16). These Scriptural examples remind us that those who do not know the depth and weight of pastoral ministry become envious and jealous of pastors, and try to force their way into the pastorate.

There are many reasons for this jealousy. One is the perception that a pastor's work is only preaching. Those who enjoy speaking in public and

25 Gula, Ethics in Pastoral Ministry, p. 7. 
expressing their own opinions are eager to become preachers. Others assume that pastors enjoy numerous benefits from church members, and enter the pastoral ministry so that they too can share in these benefits. Once in office, such people discover to their dismay that the weight of the pastoral office and its responsibilities are quite different from what they had initially thought. This discovery will force some among them to distort the pastoral ministry into what they want it to be. Unfortunately, some of those who have done this are church leaders.

\subsection{Wrong motivation for the ministry}

Onwuka sums us the wrong motivation among some Nigerian clergy: "It is no exaggeration to say that there are some preachers who joined the Christian ministry on the advice of their friends, for the purpose of what they will gain in terms of material wealth, or from their mere desire for clerical dignity. Others ... decided to join the ministry in order to be famous and popular, and to gain worldly honour and riches." ${ }^{26}$

Some people are attracted to the pastorate largely for the benefits - the fame, glamour, and assumed respect, financial and material prosperity rather than for any desire for actual ministry.

Pastors who are in the ministry for a wrong reason are there not to give to the flock but rather to gain from them. Mark D. Futato observes that the shepherd's motivation should be to benefit the flock rather than to benefit themselves. ${ }^{27}$ Jesus sacrificed all so that we might live (see Phil 2:5-11). Pastors should follow this model of sacrifice and sheep-centeredness.

\subsection{Unbelievers in the ministry}

In Matthew 7:21-23, Jesus says that at the last judgement he will tell some who claim to have prophesied and done miracles in his name "I never knew you". These words remind us that there may well be unbelievers in the pastoral ministry. Such people may know and speak the language of the church; they may technically and professionally follow the sequence of church liturgy; and they may impress the congregation with their much

26 Onwuka, The True Minister of God, p. 125.

27 Mark D. Futato, “The Book of Psalms," in Philip W. Comfort (ed.), Tyndale Cornerstone Biblical Commentary, Volume 7 (Carol Stream, Illinois: Tyndale House, 2009), p. 103. 
religious rhetoric and semantics, yet, they still remain what they are unbelievers. Yet few respondents to the survey (1.7\%) admitted that the current paradigm shift suggests that unbelievers may well be parading themselves as pastors.

\section{The implications of the paradigm shift in ministry}

The Nigerian topography of pastoral ministry has been described as "an era of confession without commitment". ${ }^{28}$ Many claim to be Christians but show no evidence of commitment to Christ. Consequently, important qualifications for the pastorate such as spiritual maturity, a clear conscience, personal integrity and moral character (see Acts 24:16; 20:26, 33-35; 2 Tim $1: 3$ ) are being jettisoned in favour of self-glorification and the acquisition of material wealth. This situation has serious consequences for the flock, for pastors, and for the power of the gospel.

\subsection{Effects on the flock}

Psalm 23 depicts Yahweh as Israel's shepherd-king whose rod and staff offer protection and guidance to the flock. But pastors, whose very title means "shepherd", show little concern for their flocks. Rather than ensuring that their people receive spiritual nourishment and have their material needs met, and administering corrective discipline where needed, contemporary shepherds may hide behind heavy security barricades and flaunt their wealth rather than using their rod and staff. Such shepherds prioritize their own needs and comfort over the needs of the sheep. Not surprisingly, needy and hurting church members are neglected and may well stray from the fold.

John Goldingay has described Psalm 23 as a psalm of trust. ${ }^{29}$ As shepherds, pastors too must demonstrate professionalism and integrity so that church

28 O. O. Berekiah, “The Deuteronomist's Perspective on the Effects of the Corruption of Worship on the Israelite Society: A Lesson for the Contemporary Nigerian Society", in S. O. Abogunrin (ed.), Biblical Studies and Corruption in Africa. Biblical Studies Series Number 6. (Nigeria: Nigerian Association for Biblical Studies, 2007), p. 57. Many in the pastoral ministry also lack spirituality, passion, burden, and the inner motivation for the ministry.

29 John Goldingay, "Psalms Volume 1: Palms 1-41," in Tremper Longman (ed.), Baker Commentary on the Old Testament Wisdom and Psalms (Grand Rapids, Michigan: 
members can look up to their pastors in trust and confidence, just as sheep look to a human shepherd for care, provision, protection, and guidance. But some insensitive and unprofessional pastors betray their people's trust and the essence of congregational ministry. Church members may find that some deeply personal issue they have shared with the pastor becomes public knowledge as the theme of a sermon. Such public betrayal shakes people's confidence in their pastors, and means that members will not share their struggles and hurts with their pastors. Instead they struggle on alone, and are at risk of being attracted to false shepherds.

Pastors with a distorted understanding of ministry can also lead their flock into gross biblical and theological error. People may come to see prosperity, miracles and materialism as the essence of Christian spirituality. In Nigeria, where the influence of African traditional religion is still pervasive, it is all too easy for people to substitute cult for conduct, and think that religious rituals and sacrifices guarantee salvation or impress God and earn his favour. ${ }^{30}$ Such error leads people to cloak dishonesty with noisy Christianity without spiritual productivity. Sadly, the Nigerian religious climate is one in which "religion has become a camouflage for different atrocities in our society." ${ }_{11}$

\subsection{Effects on the shepherd}

The presence of neglectful and wicked shepherds is nothing new, as any study of Jeremiah 23 and Ezekiel 34 reveals. Jeremiah and Ezekiel spoke out strongly against the leadership failures of the monarchs, nobles and religious leaders of Israel, and declared God's judgement on them. Jesus told the parable of the Talents (Mt 25:14-30) to remind his hearers that faithful service would be rewarded, while negligence would be punished.

Today some obvious negative consequences of the shift in ministerial paradigm are visible in the accusations levelled at those in clerical office and in the loss of integrity that has eroded respect for the clergy in the

Baker Academic, 2006), p. 345.

30 Timothy Agboluaje, “The Ministry of Amos in Israel and Its Socio-religious Implication for the Nigerian Nation," in Biblical Studies and Corruption in Africa, pp. 181-183.

31 B. G. Ogedegbe, "Prophet Amos' Message on Corruption: A Challenge to Christian Leaders in Nigeria," in Biblical Studies and Corruption in Africa, p. 200. 
eyes of some Christians and of the general the public. Sour and suspicious relationships and discord and division among some pastors also contribute to a decline in respect for the clerical office.

Some of those surveyed (18.6\%) said that poor ministerial relationships were also responsible for the phenomenon of pastors' refusing to work with their colleagues or enlist their co-operation and support. Such pastors do not respect, recognize, and appreciate the ministerial gifting and contributions of colleagues.

Additionally, a significant number of respondents (32.2\%) said that a pastor who is not in close fellowship with God is vulnerable to temptations to indulge in sexual immorality or embezzlement of funds or other forms of or misconduct. When they succumb to these temptations, there is still further loss of respect for pastors and pastoral ministry.

\subsection{Effects on the power of the gospel}

The gospel of Jesus Christ and his kingdom has inherent transforming power. It is expected that pastors will lead their congregations to transform society by their speech and lifestyle. The pastors' failure in this regard greatly hampers the effective spread of the gospel.

Corruption is rampant in Nigerian society, and the corruption virus has spread to the church. Je'adayibe D Gwamna asserts that "when the church refuses to expose evil or keeps mute in the face of corruption, it has become corrupt itself." 32 The church's failure to function as the prophetic voice and the conscience of society makes the power of the gospel ineffectual in society. According to Yusufu Turaki, the purpose of the church in society is that of living under Christ's commission in both its mission and message. He says, "The challenge of addressing the issues of ethnicity, racism and tribalism lies in the hands of the Church. ... If the Church in Africa is blinded and has also become oblivious to the plight of Africans in these areas, then something serious has happened to the Church." ${ }^{33}$

32 Je'adayibe Dogara Gwamna, "John the Baptist on Corruption: Drawing Lessons for the Nigerian Context," in Biblical Studies and Corruption in Africa, p. 442.

33 Yusufu Turaki, Tribal Gods of Africa: Ethnicity, Racism, Tribalism and the Gospel of Christ (Nairobi, Kenya: Ethics, Peace and Justice Commission of the Association of Evangelicals in Africa, 1997), p. 146. 
Wilbur O’Donovan agrees when he asserts, "the church urgently needs to take a biblical position on such issues as tribalism, poverty, injustice, sexual immorality, abortion, corruption in the church and in the government" ${ }^{34}$

Christians should learn some things from the secular world of business. There corporations are in competition with one another to win customers and make profit. They invest heavily in their leaders and their brands and work hard to convince potential customers about the quality and benefits of their products. If we look at the various religions competing for "market share" in Nigeria, we could say that the Christian "brand" is not doing well. The church does not have a high quality of leadership and there is little about its lifestyle that is distinct from what others offer. So the presentation of the gospel is weak. Yet the Christian religion and the gospel became a dominant commodity from the time of Jesus Christ on because of the quality of the product, the honesty of its presenters, and the method of the presentation. All of these have become sullied in Nigeria today.

The paradigm shift in the pastoral ministry in Nigeria according to $49.2 \%$ has muddied the face of Christianity and detracted from the expected positive effects of Christian testimony and the gospel in the eyes of the bewildered watching public. As Christianity in contemporary Nigeria has become anthropocentric rather than theocentric and Christocentric, 18.6\% indicated that the testimony and integrity of the church and the power of the gospel are fast losing their grip on society. An ineffectual and powerless gospel is emptied of its transforming force. As a result, Nigerian society sinks deeper into corruption and decay and, even worse, many souls are being lost.

\section{Conclusion}

The fast pace of the paradigm shift in pastoral ministry in Nigeria has negative effects on the church and society, causing harm to the gospel and to Christian spirituality. Attention is moving away from the biblical, theological and ethical tradition of ministry that is rooted in the Scriptures.

34 Wilbur O’Donovan Jr., Biblical Christianity in Modern Africa (Carlisle, Cumbria: Paternoster, 2000), p. 217. 
This casts a theological haze on Christians who are honestly seeking for truth.

The paradigm shift reveals a lack of basic knowledge about the nature, purpose, responsibility and accountability, methodology and established traditions of the pastoral ministry. An egocentric focus on personal benefits by non-converted pastors and untrained pastors also accounts for ministerial distortions. There has been an intentional glossing over of the eternal consequence of distortions in our understanding of pastoral ministry.

A repentant attitude and honest return by practitioners to the basic foundations of the pastoral ministry is the only possible antidote to the paradigm shift. The need is urgent.

\section{Bibliography}

Agboluaje, Timothy 2007. "The Ministry of Amos in Israel and Its Socioreligious Implication for the Nigerian Nation.” In Biblical Studies and Corruption in Africa (Biblical Studies Series Number 6). Edited by SO Abogunrin. Nigeria: Nigerian Association for Biblical Studies. 174-187.

Alcorn, Randy 2003. Money, Possession and Eternity. Revised and Updated. Wheaton, Illinois: Tyndale House Publishers.

Anderson, Robert C 1985. The Effective Pastor: A Practical Guide to the Ministry. Chicago, Illinois: Moody Publishers.

Berekiah, OO 2007. “The Deuteronomist's Perspective on the Effects of the Corruption of Worship on the Israelite Society: A Lesson for the Contemporary Nigerian Society", 50-61 in Biblical Studies and Corruption in Africa (Biblical Studies Series Number 6). Edited by SO Abogunrin. Nigeria: Nigerian Association for Biblical Studies, 2007.

Chinne, Zachariah 2013. Men of Gold: Rescuing the Church from the Throes of Material "Men of God". Bukuru, Nigeria: Hamtul Press. 
Futato, Mark D 2009. “The Book of Psalms”. In Tyndale Cornerstone Biblical Commentary Volume 7. Edited by Philip W. Comfort. Carol Stream, Illinois: Tyndale House Publishers. 1-450.

Goldingay, John 2006. "Psalms Volume 1: Psalms 1-41.” In Baker Commentary on the Old Testament Wisdom and Psalms. Edited by Tremper Longman. Grand Rapids, Michigan: Baker Academic.

Gula, Richard M 1996. Ethics in Pastoral Ministry. Mahwah, New Jersey: Paulist Press.

Gwamna, Je'adayibe Dogara 2007. "John the Baptist on Corruption: Drawing Lessons for the Nigerian Context". In Biblical Studies and Corruption in Africa (Biblical Studies Series Number 6). Edited by SO Abogunrin. Nigeria: Nigerian Association for Biblical Studies. 434-448.

Kunhiyop, Samuel Waje 2008. African Christian Ethics. Nairobi, Kenya: Hippo.

Michael, Matthew 2013. Christian Theology and African Traditions. Eugene, Oregon: Resource Publications.

Nahor, Samaila Hato 2015. Peddling the Gospel for Personal Profit: A Theology for Church and Mission Practice. Jos, Nigeria: Inspiration Publishers.

Oden, Thomas C 1983. Pastoral Theology: Essentials of Ministry. New York: HarperCollins.

O’Donovan, Wilbur Jr 2000. Biblical Christianity in Modern Africa. Carlisle, Cumbria: Paternoster Press.

Ogedegbe, BG 2007. "Prophet Amos' Message on Corruption: A Challenge to Christian Leaders in Nigeria". In Biblical Studies and Corruption in Africa (Biblical Studies Series Number 6). Edited by S. O. Abogunrin. Nigeria: Nigerian Association for Biblical Studies. 188-206. 
Olorin, Raphael Onovughe 2007. "Simon the Sorcerer and the Employment of Magical Powers by Pastors and Evangelists for Miracles and Church Growth in Nigeria”. In Biblical Studies and Corruption in Africa (Biblical Studies Series Number 6). Edited by SO Abogunrin. Nigeria: Nigerian Association for Biblical Studies. 472-489.

Onwuka, John C 2011. The True Minister of God. $3^{\text {rd }}$ edition. Bukuru, Nigeria: ACTS.

Peterson, Eugene H 1996. Working the Angles: The Shape of Pastoral Integrity. New edition. Grand Rapids, Michigan: Eerdmans.

Roberts, RC 1995. “Character”. In New Dictionary of Christian Ethics and Pastoral Theology. Edited by David J. Atkinson, David H. Field, Arthur F. Holmes, and Oliver O’Donovan. Leicester, England: IVP. $65-71$.

Tidball, DJ 1995. "Practical and Pastoral Theology". In New Dictionary of Christian Ethics and Pastoral Theology. Edited by David J Atkinson, David H Field, Arthur F Holmes, and Oliver O’Donovan. Leicester, England: IVP. 42-48.

Turaki, Yusufu 1997. Tribal Gods of Africa: Ethnicity, Racism, Tribalism and the Gospel of Christ. Nairobi, Kenya: Ethics, Peace and Justice Commission of the Association of Evangelicals in Africa. 